Ristekdik (Jurnal Bimbingan dan Konseling)

Vol 6, No.2, 2021, hlm.280-285

DOI: http://dx.doi.org/10.31604/ristekdik.2021.v6i2.280-285

ISSN 2541-206X (online)

ISSN 2527-4244 (cetak)

\title{
PERBANDINGAN MODEL PEMBELAJARAN ADVANCE ORGANIZER DENGAN NUMBER HEAD TOGETHER TERHADAP PENINGKATAN MOTIVASI BELAJAR FISIKA
}

\author{
${ }^{1}$ Aslamiyah Rambe, ${ }^{2}$ Ainun Mardiyah Lubis, ${ }^{3}$ Juni Erwina \\ Universitas Muhammadiyah Tapanuli Selatan \\ Aslamiyah.rambe@um-tapsel.ac.id
}

\begin{abstract}
The problem in this study is the low motivation to learn Physics of students, the less precise learning model used so that it is not uncommon for the model applied by the teacher to be not in accordance with the subject matter. Teaching and learning activities are always dominated by the teacher, so the teacher is more active than the students themselves. This study aims to determine the differences in students' motivation and learning outcomes of Physics through the Advanced Organizer learning model with the Number Head Together learning model at MAN SIABU. This type of research is experimental research, the sample in this study was taken by random sampling. The instruments used to collect data are observation sheets and tests. The test used is a test that has been validated and is feasible to use. Hypothesis testing using $t$ test, with a significant level of 5\%. The physics learning motivation of the experimental class students was obtained by 78.38\% "Enough", while the data on the control class students' motivation to learn Physics was also not much different, which was 76.84\% "Enough". Then the average value of the experimental class physics learning outcomes was 80.82 , while the control class's average physics learning outcomes were 78.88. Based on the results of the t-test analysis, it was obtained that tcount was 0.915 while ttable with $d k=66$ at the level of $=0.05$ was obtained 1.67. This shows that tcount < ttable. Thus, Ha is rejected, HO is accepted. This means that the hypothesis is not accepted, namely there is no significant difference between the motivation to learn Physics using the Advance Organizer learning model and the Number Head Together learning model in Class X MAN Siabu
\end{abstract}

Keywords: Advance Organizer, Learning Model, Motivation to Learn Physics, Number Head Together

\begin{abstract}
Abstrak: Adapun masalah dalam penelitian ini adalah rendahnya motivasi belajar Fisika siswa, kurang tepatnya model pembelajaran yang digunakan sehingga tidak jarang model yang diterapkan oleh guru tidak sesuai dengan materi pelajarannya. Kegiatan belajar mengajar selalu di dominasi oleh guru, sehingga guru lebih aktif dari pada siswa itu sendiri. Penelitian ini bertujuan untuk mengetahui perbedaan motivasi dan hasil belajar Fisika siswa melalui modelpembelajaranAdvance Organizer dengan model pembelajaran Number Head Together di MAN SIABU. Jenis penelitian ini adalah penelitian eksperimen, sampel dalam penelitian ini diambil secara random sampling. Instrumen yang digunakan untuk mengumpulkan data adalah lembar observasi dan tes. Adapun tes yang digunakan adalah tes yang sudah divalidkan dan layak pakai. Pengujian hipotesis dengan menggunakan uji t, dengan taraf signifikan 5\%. Motivasi belajar Fisika siswa kelas ekperimen diperoleh sebesar 78,38\% "Cukup", sedangkan data motivasi belajar Fisika siswa kelas kontrol juga tidak jauh berbeda yaitu diperoleh sebesar 76,84\% "Cukup". Kemudian nilai rata-rata hasil belajar Fisika kelas eksperimen diperoleh sebesar 80,82, sedangkan nilai rata-rata hasil belajar Fisika kelas kontrol sebesar 78,88. Berdasarkan hasil analisis uji-t diperoleh $t_{\text {hitung }}$ sebesar 0,915 sedangkan $\mathrm{t}_{\text {tabel }}$ dengan $\mathrm{dk}=66$ pada taraf $\alpha=0,05$ deperoleh 1,67. Hal ini menunjukkan bahwa $t_{\text {hitung }}<\mathrm{t}_{\text {tabel. }}$. Dengan demikian maka Ha ditolak $\mathrm{H}_{0}$ diterima. Hal ini berarti hipotesis tidak diterima kebenarannya yaitu Tidak ada perbedaan yang signifikan antaramotivasi belajar Fisika dengan menggunakan model pembelajaran Advance Organizerdan model pembelajaranNumber Head Togetherdi Kelas X MAN Siabu
\end{abstract}

Kata Kunci: Advance Organizer, Model pembelajaran, Motivasi Belajar Fisika,Number Head Together 


\section{PENDAHULUAN}

Fisika merupakan salah satu ilmu dasar yang mempunyai peranan penting dalam upaya penguasaan ilmu pengetahuan dan teknologi. Fisika juga memiliki peranan penting dalam berbagai aspek kehidupan. Banyak permasalahan dan kegiatan dalam kehidupan sehari-hari yang dapat diselesaikan dengan konsep Fisika. Perkembangan ilmu pengetahuan dan teknologi yang semakin meningkat, juga tidak lepas dari peran Fisika sebagai salah satu ilmu dasar yang memiliki nilai esensial yang dapat diterapkan dalam berbagai bidang kehidupan menjadi sangat penting. PerkembanganTeknologi seiring dengan semakin banyaknya pemanfaatan konsep-konsep Fisika secara umum maupun khusus.

Namun amat disayangkan proses pembelajaran Fisika, masih cenderung membosankan dan sulit dipahami oleh siswa. Pembelajaran cenderung fokus pada pencapaian target kurikulum, padahal keberhasilan proses pembelajaran Fisika tidak hanya bergantung kepada kemampuan untuk mencapai target kurikulum, tetapi juga bagaimana guru mampu memberikan stimulus awal kepada siswa agar siswa memiliki motivasi dalam pembelajaran Fisika. Sehingga, tujuan pendidikan nasional dapat terwujud.

Olehkarenaitu, motivasi belajar Fisika mempunyai peranan penting dalam berbagai bidang ilmu Fisika. Bahkan motivasi belajar bisa digunakan sebagai acuan, alat dan sebagai tujuan pembelajaran Fisika. Dengan dijadikannya motivasi belajar sebagai acuan pelajaran Fisika, diharapkan siswa ikut serta secara aktif dalam mengaplikasikan ide-ide Fisika. Para ahli pendidikan Fisika telah berpikir dan bekerja keras dalam upaya membantu generasi muda menjadi motivasi belajar yang handal.

Motivasi merupakan tenaga pendorong yang mendorong manusia untuk bertindak atau melakukan sesuatu. Sedangkan motivasi belajar adalah keseluruhan daya penggerak psikis di dalam diri seseorang yang menimbulkan kegiatan belajar, menjamin kelangsungan kegiatan belajar dan memberikan arah pada kegiatan belajar itu demi mencapai suatu tujuan. Pengaruh motivasi terhadap seseorang tergantung seberapa besar motivasi itu mampu membangkitkan motivasi seseorang untukbertingkah laku. Dengan motivasi yang besar, maka seseorang akan melakukan sesuatu pekerjaan dengan lebih memusatkan pada tujuan dan akan lebih intensif pada proses pengerjaannya. Dalam kegiatan belajar, motivasi dapat dikatakan sebagai keseluruhan daya penggerak di dalam diri seseorang yang menimbulkan kegiatan belajar, yang menjamin kelangsungan dari kegaitan belajar dan memberikan arah pada kegiatan belajar, sehingga tujuan yang dikehendaki oleh subyek belajar itu dapat tercapai.

Rendahnya motivasi belajar Fisika siswa disebabkan oleh banyak faktor antara lain kurangnya pendekatan pembelajaran Fisika dalam pengembangan motivasi belajar siswa, model pembelajaran yang digunakan kurang 
bervariasi, kurang menariknya penyajian materi

dalam kegiatan belajar yang disampaikan oleh guru dan kurangnya contoh-contoh yang dapat diaplikasikan dalam kehidupan nyata dan siswa lebih pasif dalam belajar karena guru lebih mendominasi dalam belajar sehingga tidak adanya kemandirian siswa dalam proses belajar mengajar.

Selain motivasi, penggunaan variasi dalam model pembelajaran juga harus dapat dilaksanakan oleh guru. Karena hanya dengan menggunaan satu model pembelajaran saja, akan membuat siswa merasa bosan, sehingga akan berakibat kepada motivasi dan keberhasilan dalam pembelajaran Fisika. Penggunaan model pembelajaran yang tepatakandapatmeningkatkanmotivasibelajarFis ikasiswasehinggahasilbelajarjugameningkat.

Dalamhalini, penelitimenggunakan model pembelajaranAdvance Organizer dan Number Head Together.

\section{METODE}

Penelitian ini merupakan penelitian eksperimen yang sengaja membangkitkan timbulnya sesuatu kejadian atau keadaan, kemudian diteliti bagaimana akibatnya. Menurut Suharsimi Arikunto (2010: 9) "Eksperimen adalah suatu cara untuk mencari hubungan sebab akibat (hubungan kausal) antara dua mengurangi atau menyisihkan faktor-faktor lain yang mengganggu. Eksperimen selalu dilakukan dengan maksud untuk melihat akibat suatu perlakuan. Sedangkan menurut Sugiyono
(2011: 107) "metode eksperimen merupakan metode penelitian yang digunakan untuk mencari pengaruh perlakuan tertentu terhadap yang lain dalam kondisi yang terkendalikan".Penelitian ini bertujuan untuk mengetahui pengaruhpenggunaan model pembelajaranterhadapmotivasibelajarsiswa. Sesuai dengan jenis penelitian ini, maka peneliti menggunakan dua kelas yaitu kelas eksperimen dan kelas kontrol. Kelas eksperimen akan dilaksanakan proses belajar mengajar dengan menggunakan model pembelajaran Number Head Togetherdan di kelas kontrol diberikan perlakuan menggunakanmodel pembelajaran Advance Organizer.

Populasi dalam penelitian ini adalah seluruh siswa kelas XMAN Siabu yang terdiri dari 9 kelas dengan jumlah254 siswa. dan sampel yaitu siswa kelas $\mathrm{X}^{-2}$ dan kelas $\mathrm{X}^{-4}$ sebanyak 64 siswa. Kelas $\mathrm{X}^{-2}$ sebagai kelas kontrol menerapkan model pembelajaranAdvance Organizer dan kelas $\mathrm{X}^{-4}$ sebagai kelas eksperimen dengan model pembelajaranNumber Head Together.

\section{HASIL}

Hasil penelitiandan pembahasan merupakan hasil studi lapangan untuk memperoleh data dengan teknik observasi dan tes setelah dilaksanakan model pembelajaran Number Head Together di 
kelas eksperimen dan model pembelajaran Advance Organizer di kelas kontrol di kelas XMAN Siabu. Karena jumlah siswa kelas Xada 254 orang maka yang dijadikan sebagai subjek penelitian adalah kelas $\mathrm{X}$ Mia 1 dan X Mia 2, sebut saja kelas eksperimen (X Mia 1) menggunakan model pembelajaran kooperatifNumber Head Togetherdan kelas kontrol (kelas X Mia 2) menggunakan model pembelajaran Advance Organizer.

Kelas eksperimen siswa yang memiliki motivasi belajar sangat baik sebanyak 7 orang $(20,59 \%)$, motivasi belajar baik sebanyak 13 orang $(38,24 \%)$, motivasi belajar cukup sebanyak 10 orang $(29,41 \%)$ dan sisanya adalah 4 orang $(11,76 \%)$ dengan kriteria motivasi belajar kurang. Namun secara keseluruhan, motivasi belajar siswa pada kelas eksperimen dengan nilai rata-rata 78,38\% sudah berada pada kriteria baik.

Untuk lebih jelas dapat dicermati diagram batang di bawah ini yang menggambarkan motivasi belajar fisika siswa pada kelas eksperimen sebagai berikut:

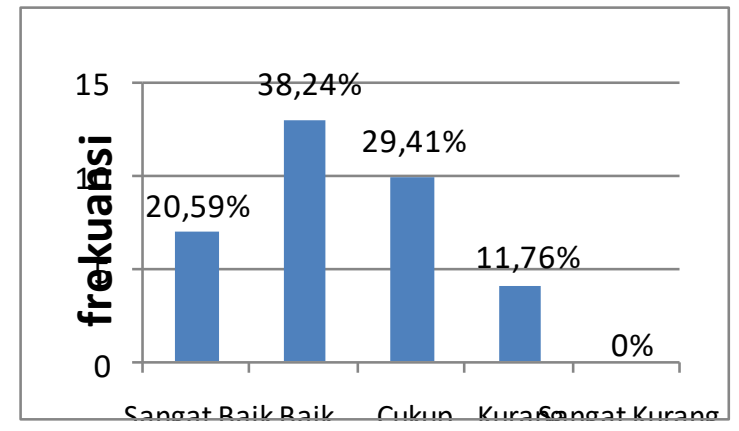

Pada kelas kontrol siswa yang memiliki motivasi belajar yang sangat baik sebanyak 2 orang $(5,88 \%)$, motivasi belajar baik sebanyak 19 orang $(55,88 \%)$, motivasi belajar cukup sebanyak 7 orang $(20,59 \%)$ dan sisanya adalah 6 orang $(17,65 \%)$ dengan kriteria motivasi belajar kurang. Namun secara keseluruhan, motivasi belajar siswa pada kelas kontrol dengan nilai ratarata $76,84 \%$ sudah dengan kriteria cukup.Adapun motivasi belajar fisika siswa pada kelas kontrol sebagai berikut:

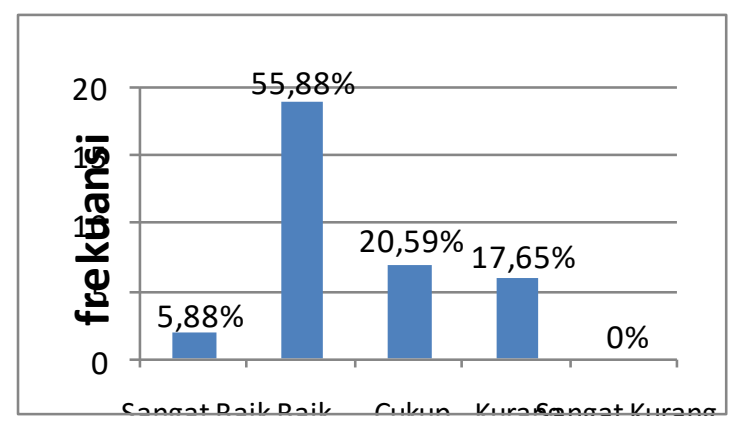

Dari data diatasdiperoleh motivasi belajar fisika siswa dengan menggunakan model pembelajaran Advance Organizer danNumber Head Together di Kelas XMAN Siabu tidak jauh berbeda dimana pada model pembelajaran Advance Organizer diperoleh rata-rata sebesar 78,38\% "Cukup", sedangkan model pembelajaran Number Head Together diperoleh sebesar 76,84\% "Cukup". Kemudian hasil belajar fisika dengan menggunakan model pembelajaran Number Head

Togetherpadakelaseksperimensebelumdiber 
ikanperlakuandiperolehnilai

pretest

64,82tetapisetelahdiberikanperlakuanmenga

lamipeningkatandandiperolehnilai rata-rata

posttest 80,82. Demikianjugadenganhasil

belajar fisika dengan menggunakan model

pembelajaran

Advance

Organizerpadakelaskontrolsebelumdiberika nperlakuandiperolehnilai rata-rata pretest 65,82tetapisetelahdiberikanperlakuanmenga lamipeningkatandandiperolehnilai rata-rata posttest 78,88 .

Jika dilihat dari hasil analisa data menggunakan uji $\mathrm{t}$ pada taraf $\alpha=0,05$ ternyata $t_{\text {hitung }}=0,915$ dan $t_{\text {tabel }}=1,67$. Dimana $t_{\text {hitung }}<\mathrm{t}_{\text {tabel }}$ maka $\mathrm{Ha}$ ditolak $\mathrm{H}_{0}$ diterima. Hal ini berarti hipotesis tidak diterima kebenarannya yaitu Tidak ada perbedaan yang signifikan antara hasil belajar fisika dengan menggunakan model pembelajaran Advance Organizerdan model pembelajaranNumber Head Togetherdi Kelas X MAN Siabu.

\section{Daftar Rujukan}

Arikunto, Suharsimi, 2005,Manajemen Penelitian. Jakarta : PT Rineka Cipta.

Suharsimi, 2006,Prosedur Penelitian Suatu Pendekatan Praktik, Jakarta : PT Rineka Cipta.

Bahri dan Aswan Zain, 2010, StrategiBelajarMengajar, Jakarta : RinekaCipta.
Dimiyatidan Mudjiono, 2006, Belajar dan Pembelajaran, Jakarta: Rineka Cipta.

Pembelajaran,
$\begin{aligned} & \text { 2008, } \\ & \text { Cipta. }\end{aligned}$

Djamarah, Syaiful Bahri, 2008, Psikologi Belajar, Jakarta: Rineka Cipta.

, 2010, belajarpembelajaran, Jakarta: RinekaCipta

Faturohman, Pupuh, dkk, 2011, MengembangkanProfesionalisme Guru, Bandung:

Hamalik,Oemar,2004, ProsesBelajarMengajar,Jakarta:Bu miAksara.

,2008, KurikulumdanPembelajaran, Jakarta: BumiAksara.

2011,Perencanaan Pengajaran Berdasarkan Pendekatan Sistem, Jakarta: PT Bumi Aksara.

2011, Proses Belajar mengajar, Bandung : Pustaka Setia

Hamdani, 2011, StrategiBelajrMengajar, Bandung: PustakaSetia.

Hamzah B. Uno, 2010,Profesi Kependidikan, Jakarta : PT Bumi Aksara.

Hamzah dan Masri Kuadrat, 2009, Mengelola kecerdasan dalam pembelajaran. Jakarta : PT Bumi Aksara.

https://pingkrystal.blogspot.co.id/2016/12/r eview-model-pembelajaranadvance.html. 
http://selametkamsompd.blogspot.co.id/201 5/09/model-pembelajaran-advanceorganizer.html.

http://modelpembelajarankooperatif.blogsp ot.co.id/2012/08/numbered-headtogether-nht.html

http://doubleddodewii.blogspot.co.id/2015/ 03/makalah-motivasi-belajardan.html

Ibrahim, 2000, Model Pembelajaran NHT, Bandung: Alfabeta.

Muhammad Nur, 2004, Model Pembelajaran, Bandung: Pustaka Setia.

Sagala, Syaiful, 2012,Konsep dan Makna Pembelajaran, Bandung : Alfabeta.

Santrock, 2007, Aspek-Aspek Motivasi Belajar: Jakarta, Rineka Cipta.

Sardirman, 2000, Aspek-Aspek Motivasi Belajar: Jakarta, Rineka Cipta.

Slameto,2010,Belajar dan Faktor - faktor yang Mempengaruhinya,Jakarta: RinekaCipta.

Sudjana. 2006,Metoda Statistika, Bandung : Tarsito.

Suherman. 2008, StrategiBelajarMengajar, Jakarta :Ri nekaCipta. 